\title{
Higher education in dark times: from the democratic renewal of Brazilian universities to its current wreck
}

\section{Pedro Fiori Arantes}

To cite this article: Pedro Fiori Arantes (2021): Higher education in dark times: from the democratic renewal of Brazilian universities to its current wreck, Policy Reviews in Higher Education, DOI: 10.1080/23322969.2021.1872412

To link to this article: https://doi.org/10.1080/23322969.2021.1872412

曲 Published online: 22 Jan 2021.

Submit your article to this journal $\widetilde{ }$

Џ Article views: 90

Q View related articles $₫$

View Crossmark data $₫$ 


\title{
Higher education in dark times: from the democratic renewal of Brazilian universities to its current wreck
}

\author{
Pedro Fiori Arantes \\ Federal University of São Paulo-Unifesp, São Paulo, Brazil
}

\begin{abstract}
This article discusses the recent expansion and democratization of Brazil's higher education system from the beginning of the twentyfirst century to the present, concluding with its contemporary clash with the far-right government, which has placed universities and scientific knowledge under attack - an experience had around the globe. In the last two decades, Brazilian public universities have become more diverse in terms of the class and racial backgrounds of students, as well as their larger expansion with new campuses in the hinterlands, the Amazon, and the peripheries of metropolitan areas. Private higher education has also expanded enormously - in part, thanks to capital concentration, inflow of foreign capital, massive public subsidies and oligopolistic strategies. In both public and private sectors, Brazilian higher education has experienced a renascence. However, since 2018, the new power bloc, concentrated around President Bolsonaro and the far right, chose Public Universities and the National Science and Research system as one of its main targets. The current regressive moment in Brazil it is not an exception, in different countries universities and science are under attack. Ultimately, this article seeks to contribute, not only to a better understanding of Brazil's on-going experience, but also to the larger public debate on higher education policy in the Global South and other countries facing similar challenges.
\end{abstract}

\section{ARTICLE HISTORY}

Received 12 June 2020

Accepted 23 December 2020

\section{KEYWORDS}

Higher education; public universities; quotas; public policy; Brazil

\section{Introduction}

Brazil is one of the main players of the so-called 'Global South', in addition to being one of the members of the BRICS group of emerging national economies (with Russia, India, China and South Africa). It also has the largest territorial area, biodiversity and GDP of the Southern Hemisphere. However, Brazil is, at the same time, a country with great social, economic and regional inequality; has a history embedded and anchored to its legacies of colonial rule and slavery; is troubled with an unstable democracy, an inheritance from 46 years of two long dictatorship in the twentieth century; and remains under economic subordination in the global capitalist system and its international division of labour. It has also been deindustrialized since the late 1970s and become increasingly dependent on extensive (and often predatory) production of commodities, 
agribusiness and mining. From a political standpoint, after 21 years of civil-military dictatorship (1964-1985), the country has been rebuilding its rule of law, and political and civil institutions to ensure its democracy, including the autonomy of its university, and freedom of thought, teaching and research, as guaranteed by the 1988 Constitution.

During the 1990s, Brazil adopted austerity policies, radical market opening, and a neoliberal economic agenda - as seen throughout the globe during this period, under the tutelage of the International Monetary Fund and the World Bank. The university system has remained stagnant, especially the public universities, which are the nation's backbone for research and scientific knowledge production. In the beginning of the twenty-first century, despite the on-going liberal economic environment, Brazil witnessed a renewal of its higher education system, with important qualitative and quantitative changes - driven particularly by the economic growth within the 14 year-period of progressive governments headed by Luiz Inácio Lula da Silva (2003-2010) and Dilma Rouseff (2011-2016), both of whom from the Workers' Party (Partido dos Trabalhadores, PT). In 20 years, undergraduate enrolment multiplied fourfold, today reaching 8.29 million students (the equivalent to $21.5 \%$ of the young people between ages 18 and 24 years in Brazil in 2020, according to PNE Observatory) (see, Graph 1).

This huge expansion took place in both the public and private higher education systems - on the one hand, in a complementary way, expanding the number of enrolments and meeting the needs of diverse training profiles for different students, and, on the other hand, in an aggressive form of competition, since they disputed the legal and regulatory frameworks, the public funds, research grants, subsidized financing and, most importantly, the students themselves. As this article will show, the dynamics of each sector operated distinctively, given the differing nature of public and private institutions, their distinct knowledge production and purpose, the very roles of students (envision as either citizens or consumers) and of professors (as either public officials with full stability and tenure track or as private salaried employees, generally hourly workers with a high staff turnover), and in their missions (as either the providers of free, public education or as the providers of a private service to consumers).

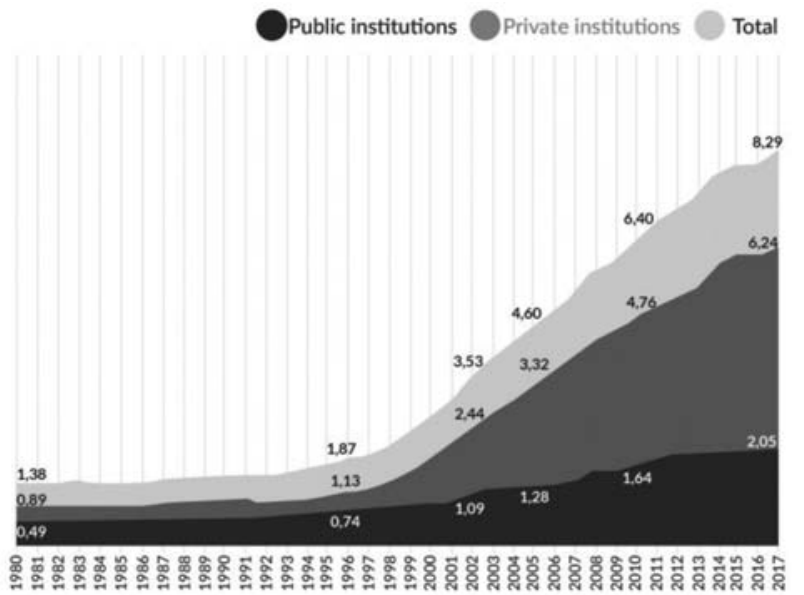

Graph 1. Total undergraduates in Higher Education in Brazil (in millions). Source: Sindata, in Semesp, 2019 with INEP Census data. 
The public sector in Brazil includes 109 federal, 124 state and 63 municipal higher education institutions (INEP, Census 2019); today, it remains completely tuition-free, from the undergraduate to the doctorate level, with an average of two million students (see, Graph 1). Public universities in Brazil house almost all major research centres in the country and account for $95 \%$ of the national scientific production (Clarivate Analytics 2017). They indicate a much higher level of teaching and research than the private institutions at any ranking. Of the 20 best universities in Brazil, 18 are public, according to the official ranking of the Ministry of Education.

The private sector has shown a greater expansion in higher education than the public, reaching in 2018 about $3 / 4$ market share (INEP Census, 2019) and $87.1 \%$ of new enrolments (PNE Observatory 2020). This expansion was the result of qualitative changes in terms of capital concentration, Initial Public Offerings on the stock market, inflow of foreign capital, massive public subsidies and the implementation of 'oligopolistic strategies' (Chaves 2010; Marques 2013), and as a result, creating giant companies, such as Kroton, which boasts the largest number of undergraduates in the world (815;332 according to Hoper 2020). As the vast majority of private institutions are not of equivalent excellence when compared with public institutions, their market focuses primarily on students who fail to pass the competitive entrance exams of public universities, offering a mass product at low-cost, low-quality, often standardized with a high concentration of online teaching.

In the public sector, strong efforts to democratize access changed the previously white, urban and elitist student and curricula profile into a more diverse and inclusive learning environment. Such diversification can be observed in terms of class, income, gender, race and high school origin of students, thanks to an aggressive quota policy, the introduction of new learning topics and methodologies, and, above all, the new location of university campuses built in the hinterlands, the Amazon, and in the peripheries of the metropolitan areas (like São Paulo, Rio de Janeiro, Brasília and Recife) (Marques and Cêpeda 2012; Vinhais 2013). As will be shown later in this article, the data on the democratization of public universities in Brazil are impressive and commonly presented internationally as a model for transforming an elitist educational system into a diverse, inclusive and multi-ethnic one.

The article will focus primarily on a critical discussion and assessment of the Lula and Dilma periods, analysing the contradictions, limits and consequences of the strong public and private higher education expansion during this 14 year period (2003-2016). Since 2014, there has been a succession of crises (economic recession, political instability, Dilma's impeachment and numerous corruption scandals) until the election of 2018 with the success of far-right president, Jair Bolsonaro, through a previously unseen campaign of massive disinformation dissemination via big data and social networks - a phenomenon also occurring in other countries recently.

The new power bloc around Bolsonaro chose Public Universities and the National Science and Research system as one of its main targets. Authoritarian, anti-science and anti-humanities trends are present in the measures and pronouncements of the President and his Education Minister. Examples include the systematic reduction of university and science public expenditure; defamation of public university faculty and their knowledge production, especially in the humanities fields; and attacks on university rectors (Brazilian designation for the head of the institutions), managers and professors, aiming to limit the internal democracy of these institutions, their autonomy and freedom of thought (Leher et al. 2020). 
The article will first present and analyse the historical context and relevant data surrounding the expansion of public and private university systems, based on information from the official educational census and database, workers and employers' organizations, thematic reports by universities and its forums, legislation and regulatory frameworks, and the national treasury budget and expenditure data. Relevant graphs and visual aids will also be included.

The main aim of this article is to better understand the clash between the democratic transition of Brazilian universities, and the contemporary politically and socially regressive moment. Will more inclusive and diverse higher educational institutions be able to cope with the attacks from the far-right government whose social strength is based on misinformation, anti-intellectualism and prejudice?

Finally, this article will discuss the challenges facing higher education in contemporary democracies under turmoil. Brazil is a dramatic case with a regressive turn - although a coup has not been officially declared in relation to the events of 2016. Over the last two decades, public universities provided spaces for the cultivation of a new moral radicalism of the Left. Universities have led part of the new Brazilian progressivism, contributing to a liberal, multi-ethnic, plural gender and more diverse cultural environment. This contributed to a progressive cultural politics that stretched the moral contours of Brazil's conservative society. That is why higher education - especially the public universities - are being heavily penalized by the reactionary global turn towards the far right, with Bolsonaro's Brazil being one of the most extreme case of contemporary cultural warfare.

Brazil is not merely an exception. We have witnessed this around the world where risks to democracy or open dictatorships have imposed severe limitations on university autonomy, freedom of thought, diversity and integrity of faculties, as well as on funding for public institutions and research. In at least 20 countries, higher education is under attack, according to the latest report from Global Coalition to Protect Education from Attack (GCPEA 2018). It is for this reason that this article aims to contribute not only to a better understanding of the Brazilian case more specifically, but also to the larger public debate on higher education policy throughout the Global South and other countries facing similar challenges.

In conclusion, to face these dark times, as the Covid-19 pandemic rages on with extreme right-wing governments in power and more public expenditures cuts, situation that becomes even more drastic in highly unequal societies, with social, economic and environmental risk of collapse, we argue that, while the pandemic has created conditions for the intensification of Bolsonaro's warfare against academic and scientific knowledge, it has also cast light on the importance of public universities to Brazilian society.

\section{Situating Brazilian Higher Education within the Latin American context}

Latin America has an important university tradition, although not well known internationally, dating back to the sixteenth century, when the first universities were created in Spanish America. The very first, La Universidad Nacional Mayor de San Marcos, was established in 1551 in Lima, Peru, making it the oldest university in the Americas and one of the oldest in the world. Latin American universities also boast a central role in the worldwide modernization of the university system, as a result of the student revolt in Cordoba, 
Argentina in 1918. The so-called University Reform of Cordoba (exactly 50 years before the French 'May 68') defended the following principles: 'university autonomy, parity tripartite government [between professors, students and graduated], free university admission, freedom of teaching, public tenders for hiring new faculty, periodicity of professorships (catedras), publicity of university acts, student well-being, extension and university social orientation'1 (Ciria and Sanguinetti 2006, 37).

The Cordoba Reform brought up, at least in Latin America, that 'university reform is the same as social reform' and that 'university reform was the secret of the transformation of society' (Rubião 2013, 4.I, §3). In other words, there would be a synchronicity between university and society in its reciprocal democratization, and in the construction of a postcolonial national project.

The Brazilian university system is more recent than that of Spanish America. Although some colleges were founded by the Portuguese monarchy and in the nineteenth century during the period of the independent Brazilian Empire, it was only after the 1930s - when national institutions were modernized - that the Brazilian State established 'educational reconstruction' as one of its priorities, with the 'new school' project, led by Anísio Teixeira, a disciple of the US educational reformer, John Dewey.

The tuition-free public university system (with Federal and state universities) - with a strong emphasis on research and professional training, but also with philosophy and social science courses - was established by the national elites and local oligarchies in order to accelerate Brazil's modernization in an attempt to overcome its colonial and slavery histories. This young university system was able to globally update itself quickly, drawing inspiration from the French and German models, combining technological and theoretical influences, hiring international professors, and creating new high quality research centres (Paula 2009).

In the early 1960s, Brazil was involved in the daring endeavour of creating a new capital, deep in the country's interior, with a modern urban and architecture design: Brasília. A new university was part of the modernist vision for the city, innovative in its scientific purposes and architecture. The project, led by Anísio Teixeira and Darcy Ribeiro, sought to

make Brasília readily capable of imparting a renewing character to the undertakings of new national projects and public policies; [...] open to young Brazilians and Latin Americans as a centre for scientific research and high-level studies standard; [...] all of this in the most modern urban and architectural setting in the world. (Ribeiro 1978, 20)

This project was partially interrupted by the 1964 military coup, which also represented a turning point in Brazilian political and higher educational history, with many professors and students persecuted imprisoned, tortured and exiled by the dictatorship, in addition to those who were killed or disappeared (Cunha 1988; Motta 2014).

The authoritarian regime in Brazil (1964-1985), however, imposed a university Reform Law in 1968 and a modernization project, designed and funded in partnership with the United States Agency for International Development (USAID), which lasted from 1964 to 1976. The dictatorship understood the importance of a strong university system for its modernization programme in association with international capital. To this end, the regime invested in new campuses and infrastructures, restructured and expanded the postgraduate education system, and encouraged university centres oriented towards research and professional training in strategic areas, such as engineering, infrastructure, 
energy, biotechnology, industrial and agriculture projects. In this way, the US model was being partially reproduced, in a subordinate position, with the creation of academic departments, full-time careers (meaning, tenure track), professionalization of staff and the adoption of the academic credit system per course (Motta 2014). On the other hand, unlike the US model, Brazilian tuition-free public university and research system continued to be financed almost entirely by the State.

The public sector expanded $72 \%$ during the 1970 s, but the regime also stimulated the growth of the private sector, which more than doubled in the same period, reaching $65 \%$ of higher education enrolments (Saviani 2008). The more comprehensive, humanistic and critical perspective of universities in the 1950s and 60s (before the coup in 1964) were being overcome in the 1970 s and 80 s by an increasingly technocratic, productivist and business-oriented mind-set. Even public universities were 'invaded by a pragmatic and privatist mentality, adopting market criteria in academic decisions and business parameters in its management' (Saviani 2008, 300).

\section{Redemocratization and the new constitutional guarantee of university autonomy and freedom of thought}

After 21 years of dictatorship, formal democracy progressively returned to Brazil in 1985. In 1988, a new Federal Constitution was ratified, which was intended to design a social and democratic state for the New Republic. The 1980s was a decade of strong economic crisis (specifically, the 1984 debt crisis in Latin America that led to the oversight of the IMF and the World Bank) and, at the same time, the emergence of new political subjects, such as strong social movements, unions, and a large mass left-wing party - the Workers' Party (PT) - led by Lula da Silva.

The new Constitution, debated and approved between 1986 and 1988, mobilized several social forces in order to build a new legal framework with strong characteristics of a social welfare state, despite the nation's post-colonial condition. In the field of education, the National Forum for the Defence of Public School was created to develop proposals for the Federal Constitution and, along with other organizations, was decisive in the struggle for redemocratization (Saviani 2013).

The Federal Constitution and the Basic Education Guidelines LDB Law, which regulates and details the constitutional articles, established a commitment to the public university system and national scientific development and stipulated the following principles: university autonomy in a wide dimension (from didactic-scientific issues to management); freedom to learn, teach, research and disseminate thought, art and knowledge; ethnicracial diversity; equal conditions for access and permanence; official public higher education establishments must maintain tuition-free undergraduate and postgraduate courses; the guarantee of public funding and sufficient resources for the maintenance and development of federal institutions and national science by the Central Government; and assurance of democratic governance of public education in all levels through its rectors, deans, and councils democratically elected.

Despite constitutional guarantees, progressive regulatory frameworks, and the autonomous and advanced environment of public universities, university students were mostly from white elite and urban middle class backgrounds, who attended private high school and had better training for the universities' competitive entrance exams. The pattern of 
class segregation in Brazil imposed a dualistic educational system. In the basic education system (from kindergarten to high school), while middle and upper classes attend private school, the rest of the population (roughly 78\%) is in the public system, which remains underfunded and generally of poor(er) quality. After the universities' entrance exams, 'there is a reiteration of the dualistic education pattern, with another ideological perversity: public and free universities for the elites and private and paid colleges for the disadvantaged' (Lima 2012, 102).

Studies have shown that 'social and political inequalities in access to higher education, between institutions and courses, persisted with strong relationships with inequalities in class, gender, race and ethnicity' (Gisi 2006, 8). Tragtemberg states,

if the entrance exam [for public universities] is not the only or the more important filter of social mobility in Brazil, (...) there is no lack of research that shows that the approval of a candidate in this exam is linked to his/her family's income, controlling the rise of the subordinate classes. (2004, Chapter 15, §3)

This situation starts to change in the mid 2000s, with a strong expansion of public enrolment and the implementation of affirmative action and a radical quota policy.

\section{The recent growth of public universities alters the distribution of power and knowledge in Brazil}

During the 14 years of the four successive Workers' Party administrations in the 2000s with the presidencies of Lula da Silva and Dilma Rousseff (2003-2016), major new advances were envisioned and implemented in the public university system, as a direct result of the pressure of progressive social movements. Firstly, the number of enrolments per year in public universities has more than tripled - from 109,000 to 393,000 new places per year - as a result of promotion by the Federal Universities Restructuring and Expansion Program (Reuni), expanding access as never before (INEP Census, 2019). The number of full time tenure track professors in public universities has increased by $64 \%$ (see, Graph 2), while private institutions - which have also increased their student populations

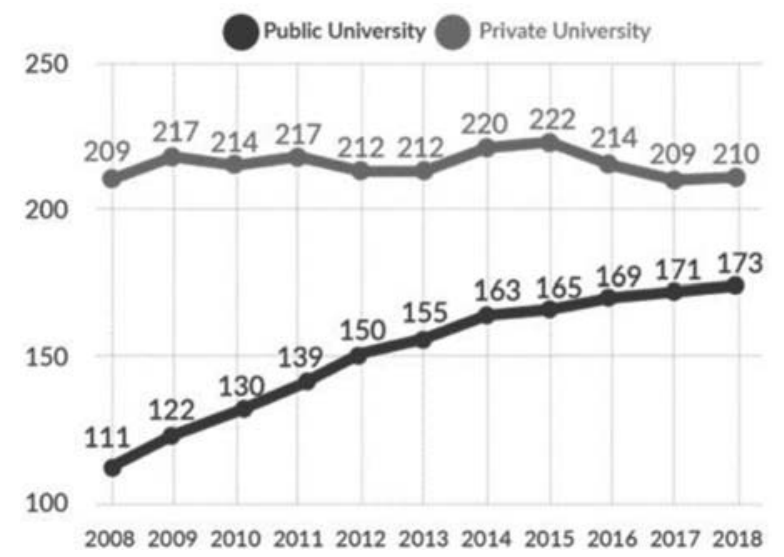

Graph 2. Higher Education Professors in Brazil, 2008-2018 (in thousands). Source: Sindata, in Semesp, 2019 with INEP Census data. 

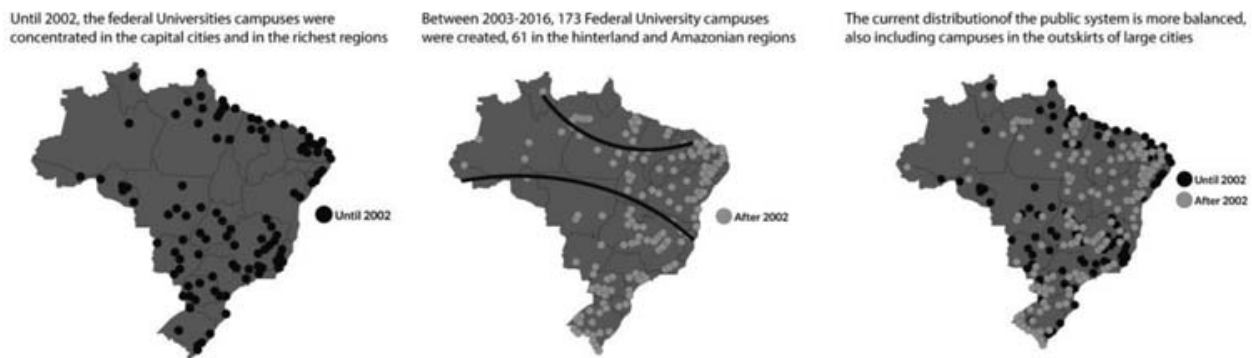

Graph 3. Expansion of new Federal Campuses in Brazil. Source: Author based on Brazilian Ministry of Education data.

by $250 \%$ since 2003 (see, Graph 1) - saw the number of professors remain stagnant, as a result of downsizing, over-exploitation, and distance learning practices.

Secondly, by a Reuni Program directive, 17 new universities and 126 new federal campuses were built in places, which had previously had no history of verified public university presence - such as: poor peripheries of large cities; semi-arid, Amazon region; and less populated and less developed hinterlands (see, Graph 3).

There has been important research that has sought to map the impact of this expansion, with positive consequences for local development, from the economic, social and cultural point of view (Vinhais 2013; Niquito, Ribeiro, and Portugal 2018). The expansion also pushed the qualification of public services, fostered extension programmes with vulnerable communities, developed new science, technology and innovation topics integrating national and global collaboration networks with local impacts.

Thirdly, although the Lula government was unable to approve its University Reform project, important institutional advances did occur. In 2004, the National Higher Education Evaluation System (Sinaes) began, with innovative metrics specifically for three dimensions (institutions, courses, and student development), bringing new parameters of quality control and comparison between institutions (Aguiar 2016). A Unified Selection Process (Sisu) was created in 2009 for admission to universities associated with the High School Quality Assessment Test (Enem), combining all public undergraduate vacancies within the same entrance exam, which greatly expanded access opportunities and intra-national student mobility (Andriola 2011); however, in certain regions, this new mobility ended up reducing local students' access to universities in their own states, with negative consequences specially for the poorest (Mello Neto et al. 2014). A constitutional amendment (EC 59/2009) was approved giving new status to the 10-year National Education Plan (PNE, 2014), and the creation of a National Education System was approved in 2014 (PNE, Art.13), foreseeing the continuity of the strong expansion of public universities (PNE, Goal 12) and establishing an increase in public investment in education from 5 to $10 \%$ of the GDP in 10 years (PNE, Goal 20).

Lastly, affirmative actions policies were created, strongly changing the undergraduates profile of public universities, an environment previously almost exclusively of the white and wealthier classes (Passos 2015). Several universities initiated quota policies before the innovative Quota Law (2012), which established isonomic criteria for all Federal Universities around the country, guaranteeing $1 / 2$ of the enrolments for students coming exclusively from public high schools, including sub-criteria of ethnicity and income 
according to the population profile of each state. More recently, a complementary law declared the inclusion of peoples living with disabilities within the quota system.

Today, the profile of the student population of public universities has moved closer to reflecting Brazilian society as a whole, in terms of income, class, gender and race. The data collected by the Brazilian National Forum of Deans of Community and Student Affairs are impressive (Fonaprace 2019). According to this data, within a fifteen-year period (20032018): the number of undergrad students that come from the lower or lower-middle income families (less then 300 dollars per capita per month) has grown from 42.8 to $70.1 \%$; students who come from public high schools has grown from 36.5 to $60.4 \%$; and the number of students of colour (those self-identifying as of African or Indigenous descent) has increased from 36.2 to $53.5 \%$. The total number of Black students grew by a factor of 5.3, while the number of pardo (mestizo) students increased by 3.5 in the same period (see, Graphs 4 and 5 respectively). In regards to gender identity and sexual orientation, in $2018,48 \%$ of students declared themselves cis women and $40 \%$ cis men and $16.4 \%$ self-identified as LGBTQI+ (Fonaprace 2019).

Today, Brazil has one of the largest public and completely tuition-free (for residents and foreigners) university systems in the world, with 296 public higher education institutions (federal, state and municipal), with 2.35 million students in 2018 (INEP Census, 2019). The Brazilian Higher Education Public System accounts for $3 / 5$ of postgraduate courses and $95 \%$ of the research done in the country (Clarivate Analytics 2017). Brazil ranks 11 th in academic research production and, among the first 15 countries, had the fifth highest average research growth rate between the years of 2008 and 2018 (see, Graph 6). Of Latin America's 25 best universities, according to Times Higher Education Ranking for Latin America (2019), 14 are Brazilians and almost all are public.

In addition to rankings - which demonstrate that Brazil is an important player in higher education and research, especially within the standards of the Global South more

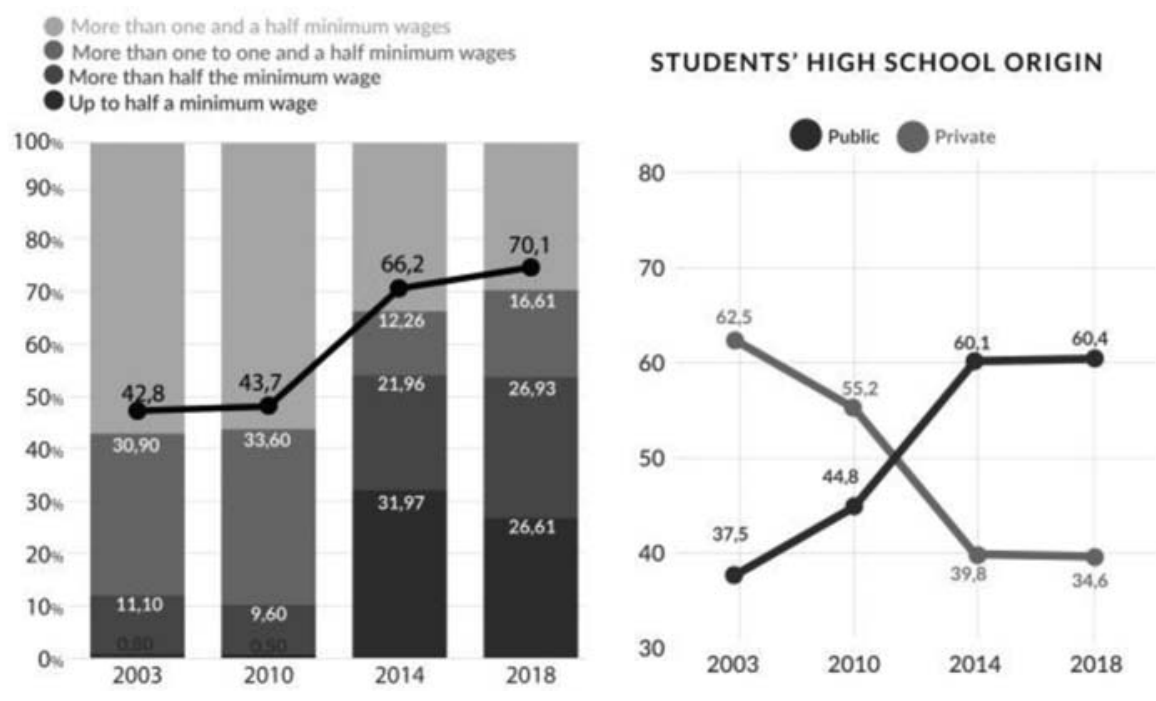

Graph 4. Changes in profile of students in Federal Universities - per family income and high school origin. Source: Author based in Fonaprace 2019 Report. 

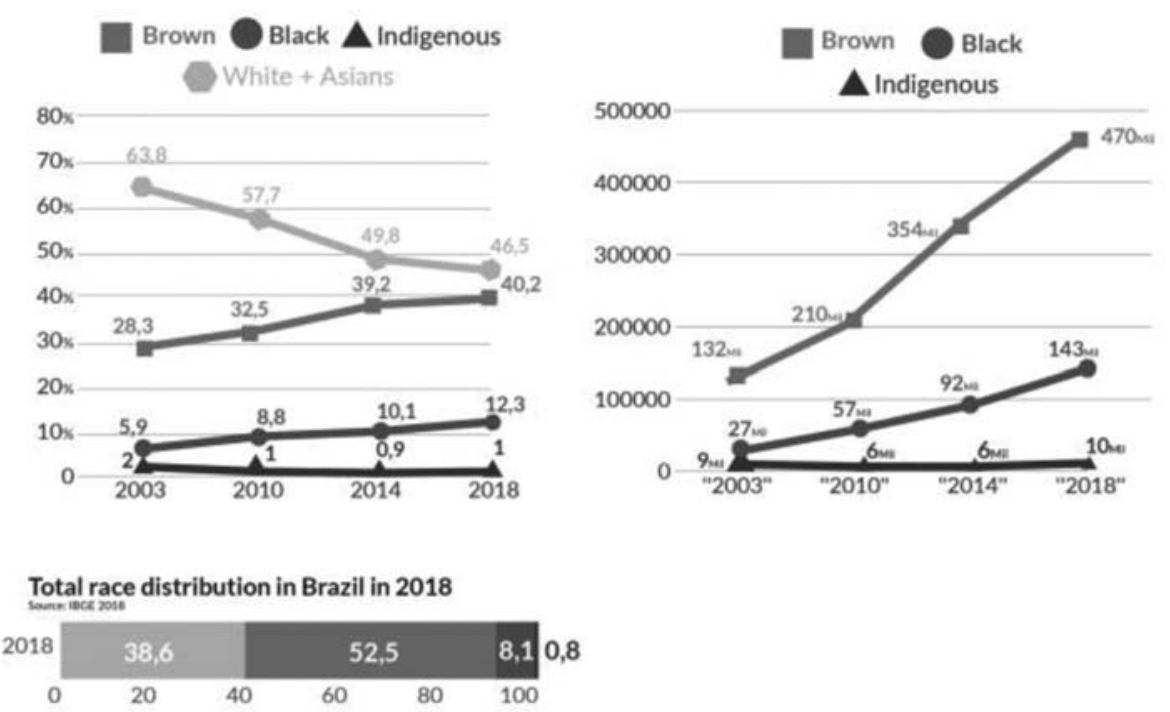

Graph 5. Changes in profile of students in Federal Universities - per colour. Source: Author based in Fonaprace 2019 Report.

generally and Latin America specifically - the most important is that the qualitative and democratic turnaround that occurred in the public university system did not imply in loss of its quality standards. And this turn is allowing, for the first time in history, to train a generation of intellectual and scientific leaders, in the most diverse places and fields of knowledge, who do not come strictly from the traditionally dominant classes.

In an assessment of the benefits of Brazil's public universities and popular classes mixing, Nilce Monfredini considers that, although universities continue to collaborate with the expanded reproduction of capital, its democratization 'now involves problems that arise in the effort to decolonize and rethink the production of knowledge, incorporating various social actors, in different approaches, assuming the joint production of knowledge' $(2019,298)$. In other words, the deep connection with the popular, working

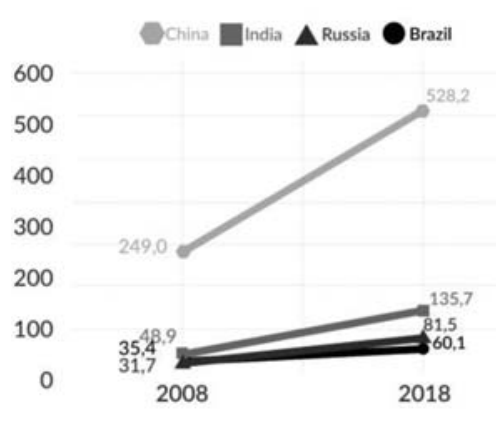

\begin{tabular}{|clccc|}
\hline Rank & Country & 2008 & 2018 & Avarage growth rate 2008/18 \\
\hline 1 & Cinna & 249,049 & 528,263 & $7,81 \mathrm{~s}$ \\
\hline 2 & United States & 393,979 & 422,808 & $0,71 \mathrm{~s}$ \\
\hline 3 & India & 48,998 & 135,788 & $10,73 \mathrm{~s}$ \\
\hline 4 & Germany & 91,904 & 104,396 & $1,28 \mathrm{~s}$ \\
\hline 5 & Japan & 108,241 & 98,793 & $-0,91 \mathrm{~s}$ \\
\hline 6 & United Kingdom & 91,358 & 97,681 & $0,67 \mathrm{~s}$ \\
\hline 7 & Russia & 31,798 & 81,579 & $9,88 \mathrm{~s}$ \\
\hline 8 & Italy & 56,157 & 71,240 & $2,41 \mathrm{~s}$ \\
\hline 9 & South Korea & 44,094 & 66,376 & $4,17 \mathrm{~s}$ \\
\hline 10 & France & 66,460 & 66,352 & $-0,02 \mathrm{~s}$ \\
\hline 11 & Brazil & 35,490 & 60,148 & $5,42 \mathrm{~s}$ \\
\hline 12 & Canada & 53,296 & 59,968 & $1,19 \mathrm{~s}$ \\
\hline 13 & Spain & 44,191 & 54,537 & $2,13 \mathrm{~s}$ \\
\hline 14 & Australia & 37,174 & 53,610 & $3,73 \mathrm{~s}$ \\
\hline 15 & Iran & 17,034 & 48,306 & 10,99 \\
\hline
\end{tabular}

Graph 6. Brazil and BRIC countries in scientific research ranking. Source: National Centre for Science and Engineering Statistics, National Science Foundation, Scopus abstract and citation database, 2019. 
class and multi-ethnic groups is 'inducing the (re)creation of the university itself' (ibid, 299). As a direct result, Brazil's current far-right government has elected public universities as one of its main targets of attack.

\section{The oligopolistic expansion of Private Higher Education and its giant companies}

Even more dramatic than the growth of the public sector was the recent super-expansion of the private sector of higher education, which currently accounts for more than $3 / 4$ of the nation's undergraduate students. It is impossible to understand the higher education system in Brazil without a brief overview of the private education sector, its expansion, dynamics, agents and interests. From the second half of the 1990s to the present day, the private higher education system grew almost five times, opening and concentrating capital, attracting investment funds and capturing public subsidies, in an oligopolistic way (Chaves 2010; Marques 2013; Chaves and Amaral 2016).

The first phase, during the neoliberal administration of then-President Fernando Henrique Cardoso (1994-2002), began with the landmark that was the new Basic Education Guidelines LDB Law (1996). LDB made rules for private higher education more flexible, allowing private universities to register themselves as a for-profit organization, and following the guidelines of the international multilateral organizations to the sector (Cunha 2003; Chaves 2010). This allowed a huge growth of the sector in just 6 years, increasing their number of undergraduates by 2.16 (from 1996 to 2002) (see, Graph 1). Private educational groups gradually exerted more influence over the National Council of Education and successfully lobbied for favourable changes in public regulation and financing (Cunha 2003; Amaral 2008).

In the second phase, during Lula's administration (2003-2010), public universities grew and spread, as shown previously; however, the government intended to do the same, concurrently, with private educational institutions, quickly expanding enrolments on a large scale. To this end, Lula's government gave tax exemptions, public subsidies and new regulation to encourage "educational businesses" and "concentrating capital", with the creation of large companies, publicly traded on the stock exchange, a new round of mergers and acquisitions, and foreign capital inflows' (Chaves 2010, 491). There was a qualitative change, with the transfer of 'private, regional and family-run companies to the control of international investment funds and private equity' (Tavares 2014, 92).

These students/'customer-consumers', as mentioned previously, are from lowermiddle class and working class backgrounds, who sought low-cost courses for basic training in an economy that was growing at 5\% per year on average allowing greater social mobility. Since 2005, the private sector benefited from a generous programme created during this administration, which granted full or partial scholarships to low-income undergraduate students (University for All ProUni, 2005), in exchange for tax exemptions for the private institutions that join the programme, optimizing the occupation of its idle vacancies (Tavares 2014; Chaves and Amaral 2016; Lins 2017).

The huge expansion of private enrolments increased competitiveness in the sector and tuition prices dropped sharply until 2010. This trend was deepened with the global crisis of 2008 - which impacted several sectors, including higher education - resulting in an increase in vacancy rates and a severe reduction in monthly fees (see, Graph 7). This resulted in a decrease in profits and an increased risk of company failure. The largest 


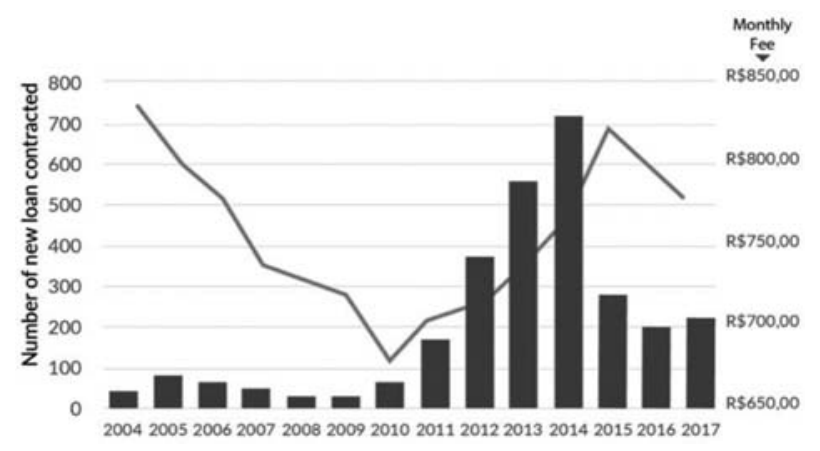

Graph 7. Average Monthly Fee (line) and FIES number of loans contracted (columns). Source: Author, based on Semesp, 2019 with FNDE/Ministry of Education data.

Brazilian higher education company, the Kroton Group (conceived and opened by Advent, a global private equity fund), had a negative EBITDA (Earnings before interest, taxes, depreciation and amortization) in 2009 and 2010 and the shares plunged to a face value of less than US\$1 (Janus Investments Report 2019). As a result, the sector began to demand a national plan to increase demand and reduce vacancies.

This conjuncture is the base of the third phase, which occurred during Dilma's administration (2011-2016). The government focused on a plan to rescue private education companies from the profit crises, with a major injection of new public funds through direct Student's Loans Financing Subsidy Program (FIES). This Loan Program, until then, was a secondary subsidy policy, serving an average of 50,000 students per year (see, Graph 7). Since 2011, the programme grew dramatically (and unsustainably), transferring public funds through the issuance of government bonds to subsidize the private sector with up to 700,000 new contracts per year - until 2014, when Brazil faced a new economic crisis (Lins 2017). FIES had high payment default (49.8\%, according to Lins), low public control, no criteria for allocation, and no risk analysis; in other words, this meant a significant transfer of public resources to the private sector, which reached $14.2 \%$ (2015) of the entire federal budget for education (Chaves and Amaral 2016, 66). The programme allowed both the reduction of vacancies and the opportunity for private institutions to increase in real terms the monthly tuition fees by $21 \%$ in average values between the years of 2010 and 2015 (see, Graph 7). With decisive support from FIES, the Kroton Group, among others, leveraged its stock price sevenfold (in 5 years) since 2011 and reached a record profit for the sector in 2016, with US\$570 million in EBITDA (Janus 2019).

The crisis was also an opportunity for an even greater concentration of capital: 'in 5 years there were 138 mergers or incorporations in the education segment' (Tavares $2014,96)$. The new round of mergers and acquisitions led to the emergence of giant companies within this sector (see, Graph 8). In 2013, Kroton Group has become the largest private education group in the world in terms of the number of total enrolments (Perez 2013). Giant companies start to dominate the financing, loans, public subsidy, and market regulation - in a clear oligopolistic strategy, which was eventually blocked by CADE, the Brazilian body that guarantees market competition (Tavares 2014; Lins 2017).

The sector continues to expand with few high-cost, high-level institutions, and the vast majority in the model of low-cost, low-quality binomial, progressively expanding distance 


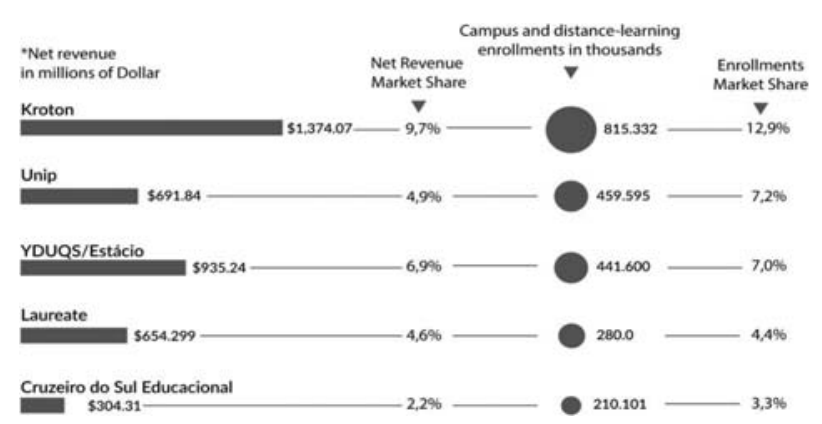

Graph 8. The top 5 giant companies in Private Higher Education in Brazil, Net Revenue (in millions of US dollars) and Market Share. Source: Hoper Education Consulting, 2020 report. 1 dollar $=3,87$ reais (30/ 12/2018).

learning since 2005, with a new (de)regulation for online courses (Alonso 2014; Sousa 2019). While much of the international economy rose after the $2008 \mathrm{Global}$ Crisis, the economic depression deepened in Brazil in 2014. Mass unemployment and a drop in public revenue led to a halt in the expansion of public universities and an equal reduction in the subsidy transfer for the private sector; seeking an escape, these institutions looked to increase enrolments in online distance learning, a model which grew by $40 \%$ in just 4 years, while the oncampus learning model decreased by $9 \%$ in the same period (Semesp 2019). COC Learning System, the main distance-learning company in Brazil, was bought in 2010 by the Pearson Group, the largest online education company in the world (Tavares 2014, 103).

In 2016, then-President Dilma was impeachment - argued by many to have been a coup, orchestrated by political, civil and private enemies of the PT - and was replaced by her vice president, Michel Temer (2016-2018). During this time began the forth phase (2016 to present), which is and has been marked by economic crisis and the fall in public subsidies for student loans and grants. Coupled with the online teaching model adopted in the previous phase, this sector also embraced a more aggressive policy against its workers (Per hour contracts have always been a rule in the private sector.), reducing academic staff and real wages, demanding higher productivity, and benefiting from new legal instruments from the Labour Reform and Outsourcing Law implemented by the Temer administration (Sousa 2019). The private higher education companies began even deeper 'debasing work conditions by the professor loss of control over portions of his labour process, by converting complex work into simple one, by creating teaching subcategories (as tutors), in short, by increasing exploration' (ibid, §4).

The policy of reducing and overloading faculty members in giant companies is even more evident since its personnel expenses represent just $37 \%$ of their total revenue, while in the medium-small ones (mostly family-run companies), it accounts for $52 \%$ (Semesp 2019). At present - thanks to this aggressive policy of low-cost fees, distance learning and staff downsizing - the profitability rate of these giant companies is at $31 \%$, double the rate of the rest of private medium and small institutions, which is $16 \%$ (ibid). In December 2019, Bolsonaro's government raised the limit for online components in on-campus courses from 20 to $40 \%$.

With the Covid-19 pandemic, one of the giant, internationally-owned companies, Laureate, deepened staff reduction and distance learning strategies with the use of 
robots and artificial intelligence, which was implemented within students' prior knowledge (Domenici 2020). According to Laureate, 'artificial intelligence in higher education is the new trend' for the pandemic and after (ibid).

\section{Lula-Dilma period balance on Higher Education}

During the Lula and Dilma administrations, the increase in places in higher education was impressive, going from 3.5 to 8 million enrolments at the undergraduate level, expanding from $9.1 \%$ in 2000 (IPEA 2014) to 20.5\% in 2016 (PNE Observatory 2020) of the population between 18 and 24 years. In this period, the market for 'education as business' expanded just as the 'right to education' became widely recognized. There was thus an intensification of competition between the public and private education sectors and inside them, to attract students and government funding, and to influence higher education policy, evaluation (including rankings) and regulation. The clash between education as a commodity or as a civil right produced evident paradoxes and contradictions, similar to those present in the pact for social inclusion with capital-labour conciliation that marked the Lula-Dilma period, also called 'Lulismo' (Singer 2012). The Workers' Party, in its aim to do 'reforms inside the order', sought to 'reconcile the interests of popular sectors and progressive academic intellectuals who defended public education, with the requests of education entrepreneurs' (Guimarães and Oliveira 2020, 310).

The economic growth of the Lula period (an increase of $4 \%$ of GDP per year on average), anchored in the increase in the world value of Brazilian export commodities (specifically, agriculture and mining), allowed the budget of the Ministry of Education to triple (from $\mathrm{R} \$ 32$ to 94 billion, according to the National Treasury) between 2003 and 2014, allowing for an expansion of the private sector and federal universities with subsidies and public budget. At the same time, the aggressive and successful affirmative action and quota policies has signified an important change, specifically that highquality universities are no longer just a space for the white and urban elites and middle classes.

Private expansion took place by stimulating companies to become public, launching shares on the stock exchange, resulting in an internationalization and financialization of its capital with the opportunity to transform higher education business on a new and global scale. This prompted a taking of the education market from the hands from local bourgeoisie and moving to international capital and in search of profitability compatible with stock exchange gains. This generated a financial-profit machine, in general focusing on low-cost 'educational products', with intensive use of distance learning, even in on-campus courses, and a reduction of faculty members. As demonstrated, the Lula-Dilma period oversaw the private higher education transformed into a global big business, with oligopolized giant companies, on an industrial massive scale.

The growth of the public sector was also impressive, as demonstrated previously, for several reasons. The speed of expansion was its strength and fragility. Strength in taking advantage of the political moment of the centre-left political and cultural hegemony that favoured its extraordinary impulse, and fragility for occurring without the necessary planning and sustainability. Budget cuts, even before Dilma's impeachment, began to occur since 2014, with the reduction of economic growth and public expenditure, hundreds of building works were paralyzed on the new campuses; there was a lack 
of staff for new courses - a situation worsened after 2016, with the constitutional amendment that placed a 20-year freeze on public spending.

Between 2003 and 2010, there was a certain balance between public and private expansion and the 'class conciliation pact', allowed by the economic growth, permitting rights and business to be expanded concurrently. But, since 2011 the balance started to tilt to only one side and we saw changes in Workers' Party's political strategy. In order to help the private sector whose speculative expansion did not find more students consumers (increasing vacancy rates and dropping monthly fees), the government turned its efforts to meet private capital needs, relegating support to the public sector. In response, federal universities in 2012 organized the biggest strike since 2001, stopping for four months. The claims were linked to faculty career and wages, retirement rights, and the lack of adequate infrastructure and working conditions in the expansion campuses. Even with the strike, Dilma's government managed to change the career plan by reducing the tenure track entry salary at universities, imposed a private pension funds system and reduced the pace of expansion of federal universities (Mattos 2013).

From an electoral point of view, the dramatic increase in places in higher education, whether public or private, represented an advantage for the Workers' Party. In every federal (re)election for both Lula and Dilma, 16-24 year olds voted heavily for the government. Even in the 2018 election with the success of Bolsonaro over the PT candidate, Fernando Haddad, young people voted mostly for the PT, according to the electoral survey conducted by DataFolha (2018) on the eve of the second round. Bolsonaro won the election with $55 \%$ of the valid votes against Haddad's $45 \%$, but among 16-24 year olds, Haddad had $58 \%$ and Bolsonaro $42 \%$. Nevertheless, young Brazilians did not have the strength to stop the advance of the extreme right in Brazil.

\section{The authoritarian moment in Brazil: universities under attack}

The unravelling of the Workers' Party government with Dilma's impeachment (2016) and Lula's arrest (2018) was due to several reasons - although outside of the scope of this research - involving loss of political support, corruption, persecution by the media, selective action by the justice, high unemployment rate, and economic recession.

In 2016, shortly after Dilma's impeachment, a constitutional amendment was approved, blocking the increase in public spending in real terms for 20 years; this was argued supposedly with the goal of adjusting public spending, but resulted in greater impacts on public policies. As shown by Graph 9, the expansion of investments in health and education for over a decade, and its subsequent stagnation since 2014, the beginning of the economic recession that afflicts Brazil to this day, was reinforced by the new public spending limit. The military budget was the only public spending that increased, almost doubling within these four years, and more than 6000 members of the Armed Forces occupy positions in Bolsonaro government.

In five years, the public budget for funding the maintenance of 68 Federal Universities and 41 Federal Technologic Institutes (staff expenditure excluded) decreased by $32 \%$ (see, Graph 10). In the same five years, there was a drop of $48 \%$ in federal resources for Research and Post Graduation (ibid). Cuts in the federal universities' budget started in Dilma's second term, which were further deepened with Temer's new constitutional 


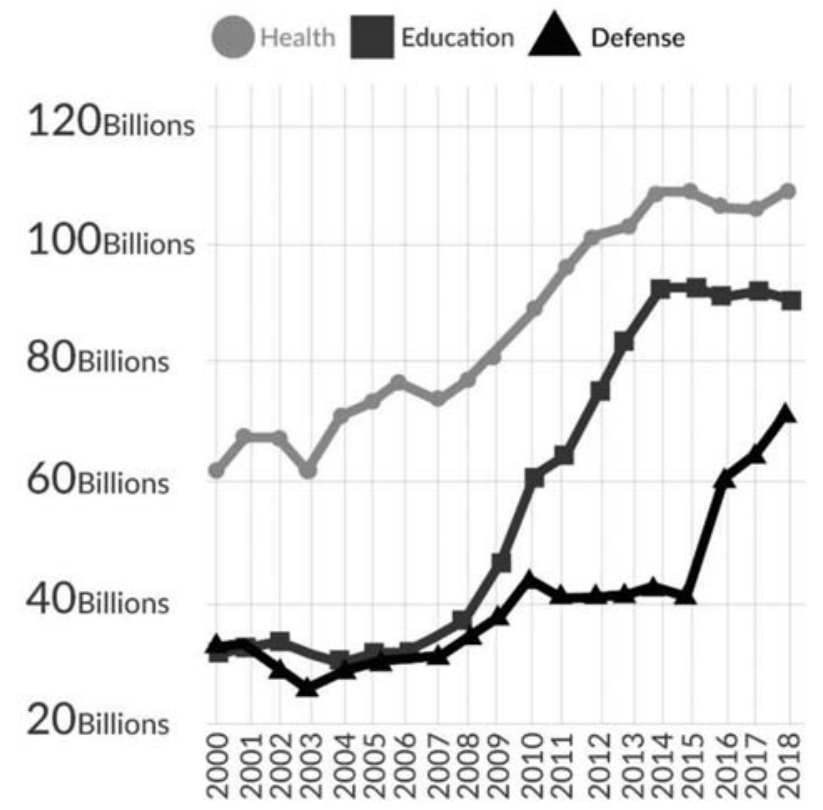

Graph 9. Rise and fall of public spending on education (in Brazilian Real). Source: Brazilian National Treasury, 2018.

ceiling for the public expenses and the situation continues to worsen with the new president. The impact of these reductions has being destructive for the entire system.

In 2018, Jair Bolsonaro was elected in the wake of polls based on strong manipulation of the electorate through big data. Cambridge Analytica operated in the same way as it did in the campaign and election of Donald Trump in the United States in 2016, in the Brexit campaign in the United Kingdom in 2016, and others (The Brazilian Report 2020). His government produces an explosive combination of radical neoliberalism (including extractive predation); racist and anti-human rights positions; weaponry and militarism (from the military and police to the criminal militias); and Pentecostal

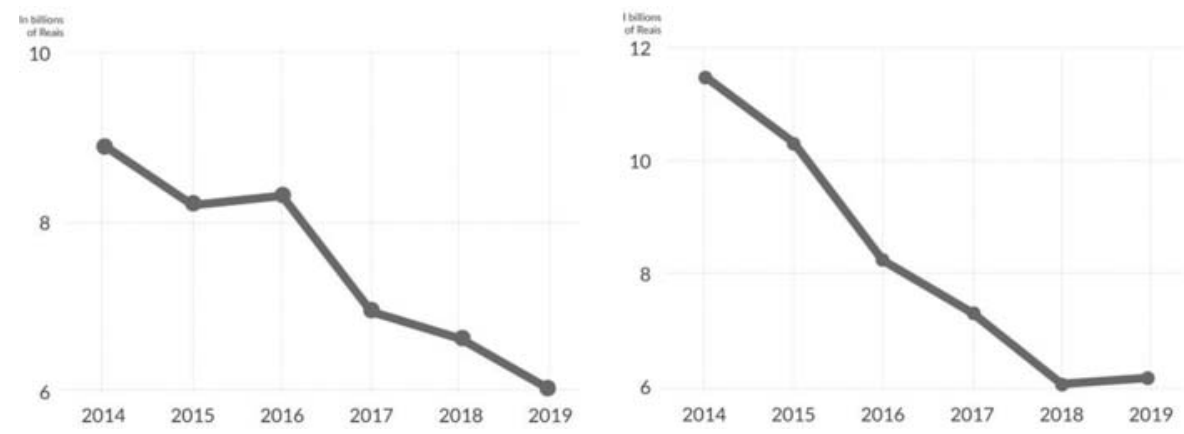

Graph 10. Decrease in budget for the maintenance of Public Federal Universities (left) and for Post Graduation grants and Science Research funds (right) (in billions of Reais with annual monetary restatement by IGP-M index). Source: Brazilian National Treasury, 2019. 
evangelical fundamentalism (Almeida 2019; Hunter and Power 2019). All of them result in attempts to assault Brazilian democracy (Nobre 2020).

The Bolsonaro government's agenda, not just for higher education, is a strong example of what the American political theorist, Wendy Brown discusses in In the Ruins of Neoliberalism: The Rise of Antidemocratic Politics in the West, i.e. the converging effects between Neoliberalism and Neoconservatism resulting in a 'antidemocratic citizenry' or 'forces of dedemocratization' (2019, chapter 3). The main reference, of course, was the recent alliance of American evangelicals with Donald Trump in reaction to Barack Obama's pluralist and globalist progressivism (Brown 2019).

In Brazil, the rise was equally surprising and resulted in a reaction to Lula-Dilma period, offering a space of possible comparison and extrapolation to this phenomenon following Obama in the US. However unlike an eccentric millionaire like Trump, Bolsonaro is a politician that came from the so-called 'low clergy' of Congress and who, until then, solely represented military interests. He attracted Neoconservatives with his anti-communist, sexist and racist discourse and forged a strategic alliance with the evangelical Christian churches, which reach $31 \%$ of the Brazilian population. On the other hand, Bolsonaro had a radical Neoliberal super minister of economics, Paulo Guedes, who trained at the University of Chicago; as a result, this allowed him to gain market confidence.

Additionally, the appointment of the four education ministers during the administration revealed the ideological profile of the Bolsonaro's government. The first, Ricardo Velez Rodriguez, was a right-wing Colombian Christian theologian; the second, Abraham Weintraub, a radical neoliberal with a background in the financial market; the third was Carlos Decotelli from the Navy and Business Schools, who lasted only four days and was removed due to fraud revealed on his curriculum vitae; finally, the fourth and current minister, Milton Ribeiro, is a Presbyterian pastor and was once vice-rector of a private religious university.

The Neoliberal Bolsonaro's agenda - of authoritarian inspiration, à la Pinochet's Chile implies in major reduction of the state's budget and personnel cuts to public universities, inexorably pushing for internal privatization, intra-system predation and its crumbling, as was seen decades ago with the public elementary education system (Sant'Ana 2018). This was also the content of the proposal report presented by the World Bank to Brazil entitled, A Fair Adjustment (World Bank 2017), which strongly recommended tuition fees for Brazilian public universities. In 2020, the Education Minister Weintraub presented to Congress a new bill for federal universities (called, Future-se), which attacked public universities' autonomy and fosters a private entrepreneurship mentality, selling research and services to the private sector, creating real estate and research public-private funds, issuing securities in the investment market, ending the tenure track and allowing hiring new professors by foundations and private companies, in precarious and temporary contracts (Unifesp 2019; Leher et al. 2020).

The Neoconservative 'ideological agenda', which seems to be an irrationalist, fundamentalist and anti-science stance, although has a much more complex cultural and political turn. We are facing moral, mythical and vigorous beliefs emerge deeply rooted in a collective psychosocial phobia against otherness. This eruption of prejudice, hatred and fears post-globalization is being driven by political and economic reactionary and proto-fascist groups aimed at build a new far (or alt-) right global hegemonic order. In Bolsonaro's Brazil, this is reflected in attacks on freedom of thought, teaching and academic research, public university autonomy and its democratic management, the social diversity 
of students and against the so-called 'cultural Marxism' that supposedly dominates Brazilian public universities, according to former Minister of Education Ricardo Velez Rodriguez's diagnosis (2006).

For both of these agendas, the Neoliberal and the Neoconservative, public universities no longer make sense as institutions in an increasingly internationally subordinate country, economically dependent, producing only commodities, violence, ignorance, fear, and social disintegration. Nowadays, Brazilian elites send their children to study abroad, especially to the United States, Canada, Australia, and Europe, and no longer need a good quality national public university system. In 2018 alone, 50,400 Brazilians undertook an undergraduate course abroad, an increase of almost $40 \%$ compared to 2017 (Martins and Correa 2020). In other words, the economic elites will form a generation of their successors completely dissociated from any further commitment to Brazilian society, democracy and institutions.

\section{The neoliberal fundamentalism against public universities}

What are the consequences of advancing the goals of the Bolsonaro's Future-se Bill (2020) and the new World Bank recommendations for Brazilian Higher Education? The main model again had US universities in mind, but in a different iteration and for a different purpose. It is not the same as USAID universities' modernization reform brought about by the military dictatorship in the 1960s-70s. Now, it is envisioned with changes to the nature and system of financing, mirroring the ways in which public universities in the United States have operated since the late 1970s.

Noam Chomsky in an article called 'The Death of American Universities' (2014) describes this neoliberal turn in the 1970s towards a 'corporate business university model' as a reaction to the relative progressivism of the American university. According to Chomsky, it was a reaction with 'a lot of concern pretty much across the political spectrum over the activism of the 1960s; it's commonly called "the time of troubles"' (Chomsky 2014). In public universities, 'people were becoming politically engaged and were trying to gain rights for groups that are called "special interests"' (idem). Student activism, the civil rights movement, the anti-war movement, and the feminism, and environmental movement made universities a melting pot. The conservative reaction came immediately with the managerial reform of the universities, precarious teaching careers and a perverse way of disciplining students: the heavy tuition debt, a trap for their futures and thus, entire lives.

The consequences of the neoliberal turn in American universities were also studied by Benjamin Ginsberg (2011) and Christopher Newfield (2016). They conclude, among others, that the effects of such transformations have gone beyond management models and have altered the very meaning and role of public universities in society. Ginsberg analyses specifically the formation of a class of professional managers who started to adopt the criteria of market efficiency into these institutions, when they should be guided by other criteria. Newfield (2016) claims that public universities have been broken by too much private funding and service to private interests, and that the problems only get worse with market-oriented, cost-focused managerialism. The social price of this indirect privatization takes several forms: universities struggle financially; students pay too much and take on exceptional educational debt; and society receives fewer nonmonetary and public benefits. Since the 2016 US presidential elections, the debate on tuition-free 
university and student debt relief has again returned to the civil and political forefront. There is currently a campaign for president-elect Joe Biden to cancel student debt, which is now calculated at US\$1.7 trillion, and to make public universities, community colleges, and vocation schools tuition-free.

In Latin America, the Chilean case reveals how disastrous the adoption of this privatist approach for public universities has been. Since the dictatorial regime from 1973 to 1990, Chile has been a major laboratory of neoliberal policies and is viewed as a model by Bolsonaro's economic team. Inspired by the US policy, public universities started to charge fees in Chile in the 1980s (on average, twice the value of the Chilean minimum wage), which has resulted in huge student debt. More recently, private universities have grown dramatically, as in Brazil, supported by state-backed financing, CAE, a programme that inspired the Brazilian FIES (Meller 2011). The cost of education per capita in Chile is the highest in the world, representing $41 \%$ of GDP per capita and university tuitions have grown in the last decade in real terms, 60\% above inflation (Meller 2011, 23-26).

Since 2006, student movements have been a protagonist in struggles against the rising cost of living and the neoliberal model with the famous demonstration of Chilean high school students became known as 'The Revolt of the Penguins', due to the students' black and white uniforms (Zibas 2008). In 2011, university students led protests, with occupations of universities and street protests in defense of 'tuition-free education' (gratuidad) (Cummings 2015).

In 2018, as a result of popular pressure, the Chilean government passed a law that foster progressive free of charge in public and even private universities, starting at $60 \%$ for students of lower income, until reaching universality. After its approval, then-President Bachelet stated, 'by making progress on tuition-free higher education, we want to build a more equitable country with equal opportunities for all. With Congress' approval, we enshrine in law a social right that should've never been in the market's hands!' (Hughes 2018). Even liberals like Sebastián Piñera, who would become president in the next term, voted in favour.

In Brazil, undoubtedly, it will be up to those who recently entered public university - a multi-ethnic, plural and popular students body, in different regions of Brazil, who, along with the faculty members, and its unions, scientific research associations, professional colleges, civil movements, and all those who still believe that it is possible to build a more just and sustainable society. It is important to note that the two major national demonstrations in defence of public education - in May and August of 2019 - have been the main mobilizations against the Bolsonaro's government up until this point.

The National Congress also is trying to impose limits to Bolsonaro. The Parliamentary Front in Defence of Federal Universities has been important to stop government attempts to interfere in university legislation and to prevent budgetary collapse. The Future-se bill does not seem to be passing easily through Congress, which recently - thanks to the mobilization of civil society and opposition governors - renewed Fundeb, a fundamental constitutional amendment and fund for transferring federal resources for public basic education in states and municipalities (Acarini 2020).

\section{The 'Cultural war': the anti-science and anti-humanities fundamentalism}

As demonstrated previous, in addition to pushing a hard neoliberal, the Bolsonaro government is also strongly engaged in a conservative 'ideological' agenda in what Hunter 
called 'cultural war' (1991) against the influence of progressive, liberal and cosmopolitan thinking. In the past two decades, public universities - with their increasingly popular, plural and multi-ethnic character of the student body - have become one of the main places of intellectual, cultural and political expansion of 'trouble' progressivism - what Minister Weintraub called universities 'bedlam' (balbúrdia): 'messing around, holding ridiculous events, with landless activists on campus, people naked, etc.' (2019). For this reason, they also became one of the main targets of attack in the cultural warfare imposed by the Neoconservatives, geared strongly towards the humanities and the legacy of educator, scholar and intellectual, Paulo Freire, in addition to what they more generally identify as 'cultural Marxism'.

Olavo de Carvalho - one of the main ideologues of the Bolsonaro administration, residing in the United States since 2005 and accompanying the rise of these conservative movements - has been the most prolific advocate for adopting the critique of cultural Marxism and globalism for the Brazilian context (Carvalho 1999). But, as with many of Brazil's cultural imports from the United States, this critique has been adapted as burlesque. Its conspiratorialist character is performatively exaggerated, in the manner of an outsider seeking authoritative recognition. Vulgar and obscure conspiracy theories from the past are revived to implicate cultural Marxists in the production of threats that are more pervasive and more imminent.

Haunted by the spectre of 'cultural Marxism' in recent years (Rodríguez 2006), segments of Brazil's new Right have often invoked a transcendental logic. The growth of fundamentalism across the country - most obviously in the form of socially conservative evangelicalism, but also in the form of dogmatic commitment to neoliberal 'reason' has contributed immensely to this as well. It is fitting that those who adhere to a closed belief system that can sustain the gratuitous contortion of facts should anoint as their leader someone they refer to as Mito (Mith), and has in his second birth name Messias (Messiah): Jair Messias Bolsonaro.

For the Neoconservatives, the opponents in the cultural battle are those who pose a threat to the white, Christian and patriarchal family, in an imaginary in which they envision public universities would be populated, i.e. by neo-communists, homosexuals, feminists, drug addicts, Black people and Indigenous peoples - all promiscuous, atheists and dangerous. During a sermon in 2018, Pastor Milton Ribeiro, current Minister of Education, condemned public universities for encouraging 'sexual practices totally without limits' (2020a) and also attacked Freire: 'He transplants values of Marxism and tries to instil them in teaching and pedagogy' (2020b).

More broadly, there is an larger attack on science itself, especially against scientific evidence that contradicts increasingly environmentally predatory policies and actions, and against the rights of Indigenous populations, minorities and human rights more broadly, which the government carries out or itself permits by other actors. More recently, the attack on science is associated with the government's criminal stance in relation to the Covid-19 pandemic, seeking to counter the globally accepted notions of social isolation and other measures to avoid the spread of Covid-19, or defending the indiscriminate use of chloroquine without scientific backing or against medical evidence (Jucá 2020).

From the perspective of the attacks on university autonomy and freedom of thought, the Bolsonaro government has great ideological and anti-democratic propensity. It resembles the policies and actions of Viktor Orbán of Hungary, which haunts the 
European Community's democratic pact. Both are close political partners and share authoritarian, militaristic, fundamentalist and racist views. In 2019, there were six meetings and visits with representatives from Brazil and Hungary. Orbán was one of the few foreign leaders present in Bolsonaro's inauguration. The Brazilian Minister of Foreign Affairs, Ernesto Araújo, afirmed 'Brazil and Hungary share values and worldviews', to which Orbán responded, 'the most apt definition of modern Christian democracy can be seen in Brazil, and not in Europe' (Rocha 2020).

The institutional situation in Brazil has not yet reached the same point as the open establishment of what Orbán himself calls the 'illiberal regime'. Rather, it has maintained the functioning of democratic institutions, albeit under pressure and growing instability. While Orbán is in his third term, Bolsonaro has just completed 2 years in office.

In Orbán's regime, the eviction of the Central European University (CEU) from Budapest to Vienna made evident the fact that universities in Hungary were under attack (Foer 2019). In this case, the Congress and Supreme Court failed to impose limitations; on the contrary, the Parliament passed a law in 2017 declaring the CEU illegal. Thus, universities and research centres are losing autonomy, and intellectuals and scientists are leaving the country.

In Brazil, public universities were defended by the Supreme Court in October of 2018 after been invaded by the police to prevent debates on democracy (Turollo 2018); and, more recently, by the president of the Brazilian Congress, who rejected a second bill from the Bolsonaro government to change the rules for nominating university rectors (Chamber of Deputies 2020). Defeated twice in this attempted of direct interference, Bolsonaro has, whenever possible, appointed rectors who were not the most voted by their respective university councils (Brazil adopts a triple list system.) in favour of right-wing candidates (who generally place third on the list), sixteen until the moment. Perceiving this president's discretionary action hurts the constitutional autonomy and democracy of universities, the Supreme Court again tries to impose limits and regulate that matter, which is still being litigated in court at this moment.

Under Bolsonaro, the federal government has also notably increased surveillance of public sector workers, from police officials to academics although not yet reaching the same attitudes as the 'liberal regime' that publish weekly lists of enemies, which oftentimes also includes dozens of academics, accused as mercenaries (Foer 2019). There are already loopholes in Brazilian anti-terror law that can be used to justify political repression as a preventive measure. University teachers (specially in the humanities field) have becomes victims of political persecution, outsourced to new right activist groups, or disguised as investigations into criminal misconduct (Valente 2020).

Both ultra-right governments in Brazil and Hungary are supported by fundamentalist Christian and evangelical bases - with regressive social and moral perspectives that underpin the so-called 'conservative wave' (Almeida 2019). These groups attack the cultural, ethnic and sexual orientation of individuals, the open and cosmopolitan environment of universities and scientific production more generally in the name of 'family' and 'Christian values'. Parallels can also be seen, as mentioned, in the United States, in the rise of the Christian Right and the growing popularity of conservative evangelicalism (Brown 2019). 


\section{Conclusion: universities responding to the pandemic and denialism}

Brazil is experiencing a moment of polarization and conflict, class struggle on one side and urban warfare on the other, growing politicization and rampant despair. One cannot predict the course of the events for the upcoming years. The Covid-19 pandemic - with its unequal and destructive impact on different social classes and racial groups - is deepening the social and economic crisis, with an increase in unemployment, misery and hunger. This will bring the country either to the brink of collapse or to a progressive and radical turn, based on strengthening solidarity and support for the public sector, renewed belief in science and the civic role of universities.

Universities may be witnessing the breakdown of the social pact that allows them to exist as part of the public sphere that simultaneously provides them their nexus and foundation. The Covid-19 pandemic has exposed this situation in many countries, not just in Brazil - although its government has been cited as one of the worst examples in the fight against the pandemic and protection of citizens (According to research published by the Deep Knowledge Group in June 2020, Brazil is in 91st place.). Bolsonaro, for example, has directly contested the points on which epidemiologists have broadly reached consensus the efficacy of social isolation and the use of masks (Chaib 2020). What appears as disorganisation or straightforward incompetence in the midst of Brazil's worst health crisis in living memory - including a directorial vacancy in the Ministry of Health for more than two months at the height of the pandemic - can be of short-term political expediency.

As the pandemic has produced political challenges for his government, Bolsonaro has also used it to intensify his assault on public universities. In August of 2020, as Brazil's official death toll surpassed 100,000 , the government informed rectors of federal universities that there would be a further cut of $18.2 \%$ in their unrestricted budgets in 2021, which are used to cover running costs (Amaral 2020). As the largest year-on-year reduction in government spending on federal universities, this could force Brazil's higher education system into collapse if Congress passes it. That public universities have responded decisively to the pandemic has, nonetheless, demonstrated a capacity to resist. Once again, the alliance between universities and Congress will be necessary to avoid collapse.

Rather than readily accepting a transition from face-to-face undergraduate education to distance learning, public universities have taken a more cautious approach, assessing the potential impact of adaptation on the learning of students in situations of greater vulnerability, with less access to digital technologies. Universities are currently acquiring computers and broadband subscriptions for students who need them, so as to reduce the possibility of exclusion from teaching and courses. Meanwhile, they have increased the provision of open and extracurricular courses. They have reached beyond the academic community, organizing online debates and establishing solidarity networks that provide healthcare, including psychological support. As such, the continuation of many university activities has contributed to the development of an open-university model.

Additionally, public universities have played an important role in disseminating scientifically grounded information on the epidemiology of the virus. Within three months of the virus reaching Brazil, federal universities launched 1200 research projects related to Covid-19, focused on prevention, diagnosis, and treatment, on hospital management, and on the implications for education, work, and income (Andifes 2020). They are also 
involved in the development of possible vaccines, many in partnership with scientific communities abroad. Public university laboratories have been adapted to increase the production of ventilators, personal protective equipment (PPE), and basic medications. And, for the first time, all of the country's 51 Public University Hospitals have come together to establish a collective procurement system.

If decades of bureaucratic development produced certain inertia within Brazil's higher education system, public universities have proven remarkably adaptable in response to the pandemic. At the same time, they have demonstrated determination to oppose government measures that would shrink the public sphere and the university's role within it. They are not alone in their resistance. Despite chronic underinvestment, Brazil's Unified Health System (SUS) has held up relatively well during the pandemic. Mutual aid networks have emerged on the periphery of cities, as communities have mobilised to protect the most vulnerable.

There is a general perception that the period of disinformation and manipulation needs to end and that society depends on knowledge and research - including in defence of the right to life. The whole world is discussing what the post-pandemic reality will be. Universities will likely play an important role in redefining principles, protocols and policies in defence of the 'right to be alive for all'. In Brazil - as in other countries haunted by authoritarian, neoliberal, and fundamentalist regression - the challenges will be immense. Public universities have demonstrated vitality and institutional capacity at this moment of the crisis. This allows us to consider how universities and the scientific community could come out stronger to act in favour of science, diversity, tolerance, cooperation and social and environmental justice.

\section{Note}

1. All the in-text citations were translated from Portuguese or Spanish to English by the author.

\section{Disclosure statement}

No potential conflict of interest was reported by the author(s).

\section{ORCID}

Pedro Fiori Arantes (1) http://orcid.org/0000-0002-6652-294X

\section{References}

Acarini, A. 2020. "Derrota de Bolsonaro e vitória da Educação: Câmara aprova novo Fundeb" [Defeat of Bolsonaro and Victory of Education: Congress Approves New Fundeb]. https://www.cut.org.br/ noticias/derrota-de-bolsonaro-e-vitoria-da-educacao-camara-aprova-novo-fundeb-f410.

Aguiar, V. 2016. "Um balanço das políticas do governo Lula para a educação superior." [A Review of Lula's Policies for Higher Education] Revista de Sociologia e Política 24 (57): 113-126. doi:10.1590/ 1678-987316245708.

Almeida, R. 2019. "Bolsonaro Presidente: Conservadorismo, Evangelismo e a Crise Brasileira." [Bolsonaro President: Conservatism, Evangelism and the Brazilian Crisis] Novos estudos CEBRAP 38 (1): 185-213. Epub May 06, 2019. doi:10.25091/s01013300201900010010. 
Alonso, K. M. 2014. "A EaD no Brasil: sobre (des)caminhos em sua instauração." [Distance Learning in Brazil: On the (Mis)leadings of Its Introduction] Educar em Revista Special Issue (spe 4): 3752. doi:10.1590/0104-4060.38643.

Amaral, N. 2008. Financiamento da Educação Superior: Entre Estado e Mercado [Financing of Higher Education: Between State and Market]. São Paulo: Cortez.

Amaral, L. 2020. "MEC deve cortar R\$1,4bi de verba de universidades e institutos em 2021" [Ministry of Education Should Cut R \$1.4 Billion from Universities and Institutes in 2021]. UOL, August, 10. https://educacao.uol.com.br/noticias/2020/08/07/mec-deve-cortar-18-do-orcamento-de-univers idades-e-institutos-em-2021.htm.

Andifes. 2020. The National Association of Directors of Federal Higher Education Institutions. A Video Summarises the Activities of Brazil's Federal Universities in Response to the COVID-19 Pandemic: https://www.youtube.com/watch?feature=emb_logo\&time_continue=2\&utm_mediu $\mathrm{m}=$ website\&utm_source=archdaily.com.br\&v=F_TdMAebYO8.

Andriola, W. B. 2011. "Doze motivos favoráveis à adoção do ENEM pelas IFES." [Twelve Reasons in Favor of Adopting the National High School Exam by Federal Higher Education Institutions]. Ensaio: Avaliação e Políticas Públicas em Educação 19 (70): 107-126. doi:10.1590/S010440362011000100007.

The Brazilian Report. 2020. Latest Cambridge Analytica Leak Points to Involvement in Brazilian Elections. https://brazilian.report/power/2020/01/09/latest-cambridge-analytica-involvementbrazilian-elections/.

Brown, W. 2019. In the Ruins of Neoliberalism: The Rise of Antidemocratic Politics in the West. New York: Columbia University Press.

Carvalho, O. 1999. "Máfia Gramsciana" [Gramscian Mafia]. Jornal Da Tarde, November 25. https:// olavodecarvalho.org/mafia-gramsciana/.

Chaib, J. 2020. "Uso de máscara é último tabu a cair, diz Bolsonaro sobre prevenção da Covid" [Wearing a Mask Is the Last Taboo to Fall, Says Bolsonaro on Covid prevention]. Folha de S.Paulo, November 26. https://www1.folha.uol.com.br/equilibrioesaude/2020/11/mascara-eultimo-tabu-a-cair-diz-bolsonaro-sobre-prevencao-da-covid.shtml.

Chamber of Deputies. 2020. "Presidente do Congresso devolve MP que permitia nomeação de reitores sem consulta às universidades" [Congress President Returns Bill that Allowed Appointment of Provosts Without Consultation with Universities]. Agência Câmara de Notícias, June 12. https:// www.camara.leg.br/noticias/668526-presidente-do-congresso-devolve-mp-que-permitia-nomea cao-de-reitores-sem-consulta-as-universidades/.

Chaves, V. L. J. 2010. "Expansão da privatização/mercantilização do ensino superior Brasileiro: a formação dos oligopólios." [The Expansion of Privatization and Mercantilization of Brazilian Higher Education: The Formation of Oligopolies] Educação \& Sociedade 31 (111): 481-500. doi:10.1590/S0101-73302010000200010.

Chaves, V. L. J., and N. C. Amaral. 2016. "Política de Expansão da Educação Superior no Brasil: O Prouni e o FIES como financiadores do Setor Privado." [Expansion Policy for Higher Education in Brazi: Prouni and FIES as Private Sector Financers] Educação em Revista 32 (4): 49-72. doi:10. 1590/0102-4698162030.

Chomsky, N. 2014. "The Death of American Universities." Jacobin, March 3. https://www.jacobinmag. com/2014/03/the-death-of-american-universities/.

Ciria, A., and H. Sanguinetti. 2006. La Reforma Universitaria (1918-2006) [The University Reform (1918-2006)]. Santa Fé: Universidad Nacional del Litoral.

Clarivate Analytics. 2017. "Research in Brazil: A Report for CAPES" by Clarivate Analytics. https://www. capes.gov.br/images/stories/download/diversos/17012018-CAPES-InCitesReport-Final.pdf.

Cummings, P. M. M. 2015. "Democracy and Student Discontent: Chilean Student Protest in the Post-Pinochet Era." Journal of Politics in Latin America 7 (3): 49-84. doi:10.1177/ $1866802 X 1500700302$.

Cunha, L. A. 1988. A universidade reformada: o golpe de 1964 e a modernização do ensino superior [The Reformed University: The 1964 Coup and the Modernization of Higher Education]. Rio de Janeiro: Francisco Alves. 
Cunha, L. A. 2003. "O ensino superior no octênio FHC." [Higher Education under the Cardoso Administration (1995-2002)] Educação \& Sociedade 24 (82): 37-61. doi:10.1590/S010173302003000100003.

DataFolha. 2018. Pesquisa eleitoral de 27 de outubro de 2018. http://media.folha.uol.com.br/ datafolha/2018/10/29/9d1a93fe17726819d7088b03c0278862.pdf.

Domenici, T. 2020. "Faculdades da Laureate substituem professores por robô sem que alunos saibam" [Laureate Colleges Replace Professors with Robots Without Students Knowing]. Folha de S. Paulo, May 2. https://www1.folha.uol.com.br/amp/educacao/2020/05/faculdades-dalaureate-substituem-professores-por-robo-sem-que-alunos-saibam.shtml.

Foer, F. 2019. "Viktor Orbán's War on Intellect." The Atlantic, June. https://www.theatlantic.com/ magazine/archive/2019/06/george-soros-viktor-orban-ceu/588070/.

Fonaprace, Brazilian National Forum of Deans of Community and Student Affairs. 2019. "5a pesquisa do perfil socioeconômico e cultural dos estudantes de graduação" [5th Research on the Under Graduation Student's Socioeconomic and Cultural Profile Report]. http://www.andifes.org.br/ wp-content/uploads/2019/05/V-Pesquisa-do-Perfil-SocioeconC3B4mico-dos-Estudantes-deGraduaC3A7C3A3o-das-Universidades-Federais-1.pdf.

Future-se Bill. 2020. Projeto de Lei 3076/2020. https://www.camara.leg.br/proposicoesWeb/ fichadetramitacao?idProposicao $=2254321$.

GCPEA (Global Coalition to Protect Education from Attack). 2018. Education Under Attack. http:// www.protectingeducation.org/sites/default/files/documents/eua_2018_full.pdf.

Ginsberg, B. 2011. The Fall of the Faculty: The Rise of the All-Administrative University and Why It Matters. Oxford: Oxford University Press.

Gisi, M. L. 2006. "A educação superior no Brasil e o caráter de desigualdade do acesso e da permanência." [Higher Education in Brazil and the Inequality of Access and Permanence] Diálogo Educacional 6 (17): 97-112. doi:10.7213/rde.v6i17.6740.

Guimarães, A., and J. M. S. Oliveira. 2020. "A educação superior no governo Lula da Silva (20032010): democratização ou subordinação à ordem do capital?" [Higher Education in the Lula da Silva Government (2003-2010): Democratization or Subordination to the Order of Capital?] In O Pânico como política, edited by F. L. Barbosa dos Santos, M. A. Perruso, and M. S. Oliveira, 307-316. Rio de Janeiro: Mauad X.

Hoper, Education Consultancy. 2020. “Cenário do mercado educacional no Brasil, 2020" [Educational Market Scenario in Brazil, 2020]. https://www.hoper.com.br/infograficos/.

Hughes, J. 2018. "Chilean Students Take Stand Against Profiteering in Education." Masterstudies, April 13. https://www.masterstudies.com/news/chilean-students-take-stand-against-profiteering -in-education-2572/.

Hunter, J. D. 1991. Culture Wars: The Struggle to Define America: Making Sense of the Battles Over the Family, Art, Education, Law, and Politics. New York: Basic Books.

Hunter, W., and T. J. Power. 2019. "Bolsonaro and Brazil's Illiberal Backlash." Journal of Democracy 30 (1): 68-82. doi:10.1353/jod.2019.0005.

IPEA. 2014. Evolução do Acesso de Jovens à Educação Superior no Brasil [Evolution of Youth Access to Higher Education in Brazil]. http://repositorio.ipea.gov.br/bitstream/11058/3021/1/TD_1950.pdf.

Janus Investment. 2019. Kroton, qual futuro para a educação? [Kroton, What Future for Education?]. https://janusinvestimentos.com/kroton-krot3-qual-o-futuro-da-educacao/.

Jucá, B. 2020. "Bolsonaro amplia uso da cloroquina admitindo que pode não ter eficácia e trazer efeitos colaterais graves" [Bolsonaro Expands Use of Chloroquine Admitting It May Not Be Effective and Bring Serious Side Effects]. El Pais, May 20. https://brasil.elpais.com/brasil/202005-20/bolsonaro-amplia-uso-da-cloroquina-admitindo-que-pode-nao-ter-eficacia-e-trazerefeitos-colaterais-graves.html.

Leher, R. et al. 2020. Future-se: ataque à autonomia das instituições federais de educação superior e sua sujeição ao mercado [Future-se: Attack on the Autonomy of Federal Higher Education Institutions and their Subjection to the Market]. São Carlos: Diagrama. https://www. diagramaeditorial.com.br/project/future-se/. 
Lima, P. G. 2012. Universidade brasileira: por uma perspectiva universal, humana e democrática [Brazilian University: From a Universal, Humanitic and Democratic Perspective]. São Paulo: AnnaBlume.

Lins, M. A. 2017. "Apropriação do fundo público pelo ensino superior privado no Brasil: a intermediação do Estado" [Appropriation of Public Funds by Private Higher Education in Brazil: State Intermediation] (PhD Dissertation). https://repositorio.ufpe.br/handle/123456789/29878.

Marques, W. 2013. "Expansão e oligopolização da educação superior no Brasil." [Expansion and Oligopolization of Higher Education in Brazil]. Revista da Avaliação da Educação Superior 18 (1): 69-83. doi:10.1590/S1414-40772013000100005.

Marques, A. C., and V. A. Cêpeda. 2012. “Um perfil sobre a expansão do ensino superior recente no Brasil: aspectos democráticos e inclusivos." [A Profile on the Recent Expansion of Higher Education in Brazil: Democratic and Inclusive Aspects] Perspectivas 42: 161-192.

Martins, E., and S. Correa. 2020. "O sonho dos brasileiros com diploma importado" [The Dream of Brazilians with Imported Diploma]. Época Magazine, February 7. https://epoca.globo.com/ sociedade/o-sonho-dos-brasileiros-com-diploma-importado-24233788.

Mattos, M.-B. 2013. "Uma greve, várias lições. A greve das universidades federais no Brasil em 2012." [One Strike, Several Lessons. The Strike of Federal Universities in Brazil in 2012] Revista Iberoamericana de Educación Superior IV (10): 135-142. doi:10.1016/S2007-2872(13)71928-0.

Meller, P. 2011. Universitarios! El problema no es el lucro, es el Mercado [University Students! The Problem Is Not the Profit, It Is the Market]. Santiago: Uqbar Editores.

Mello Neto, R., H. A. Vasconcelo Medeiros, F. da Silva Paiva, and J. L. Simões. 2014. "O impacto do Enem nas políticas de democratização do acesso ao Ensino Superior Brasileiro." [Enem's Impact on the Democratization Policies of Access to Brazilian Higher Education] Revista Comunicações 21 (3): 110-123. doi:10.15600/2238-121X/comunicacoes.v21n3p109-123.

Monfredini, I. 2019. "A Universidade viva na relação com as classes populares." [The University Alive in Relation to the Popular Classes] Revista da Avaliação da Educação Superior 24 (1): 278-304. doi:10.1590/s1414-407720190001000015.

Motta, R. P. 2014. As universidades e o regime militar [Universities and the Military Regime]. Rio de Janeiro: Zahar.

National Institute of Educational Studies and Research (INEP). 2019. Censo da Educação Superior [Higher Education Census]. http://download.inep.gov.br/educacao_superior/censo_superior/ documentos/2019/censo_da_educacao_superior_2018-notas_estatisticas.pdf.

Newfield, C. 2016. The Great Mistake: How We Wrecked Public Universities and How We Can Fix Them. Baltimore: Johns Hopkins University Press.

Niquito, T. W., F. G. Ribeiro, and M. S. Portugal. 2018. "Impacto da criação das novas universidades federais sobre as economias locais." Revista Planejamento e Políticas Públicas, n.51.

Nobre, M. 2020. Ponto-final: A Guerra de Bolsonaro contra a Democracia [Endpoint: Bolsonaro's War on Democracy]. São Paulo: Todavia.

Passos, J. C. 2015. "Relações Raciais, Cultura Acadêmica e tensionamentos após ações afirmativas." [Race Relations, Academic Culture and Tensions After Affirmative Actions] Educação em Revista 31 (2): 155-182. doi:10.1590/0102-4698134242.

Paula, M. F. 2009. "A formação universitária no Brasil: concepções e influências." [Higher Education in Brazil: Concepts and Influences] Revista de Avaliação da Educação Superior 14 (1): 71-84. doi:10. 1590/S1414-40772009000100005.

Perez, F. 2013. "Gigantes da educação" [Education Giant Companies]. IstoÉ, April 26. https://istoe. com.br/294090_GIGANTES+DA+EDUCACAO/.

PNE Brazil National Education Plan 2014-2024 13.005/2014 Law. 2014. http://www.planalto.gov.br/ ccivil_03/_ato2011-2014/2014/lei/l13005.htm

PNE Observatory. 2020. https://www.observatoriodopne.org.br/indicadores/metas/12-ensinosuperior/.

Ribeiro, D., ed. 1978. UnB: Invenção e descaminho [UnB: Invention and Deviation]. Brasília: Avenir.

Ribeiro, M. 2020a. "Minister of Education." UOL, July 12. https://noticias.uol.com.br/ultimas-noticias/ agencia-estado/2020/07/12/novas-universidades-ensinam-sexo-sem-limite-disse-ministro-daeducacao-em-2018.htm. 
Ribeiro, M. 2020b. "Minister of Education." Gazeta do Povo, October 4. https://www.gazetadopovo. com.br/educacao/milton-ribeiro-paulo-freire-marxismo-ensino/.

Rocha, C. 2020. "A política cultural na Hungria. E os paralelos com o Brasil" [Cultural Policy in Hungary. And the Parallels with Brazil]. Nexo Jornal, January 18. https://www.nexojornal.com. br/expresso/2020/01/18/A-pol\%C3\%ADtica-cultural-na-Hungria.-E-os-paralelos-com-o-Brasil.

Rodríguez, R. V. 2006. "O marxismo gramsciano: pano de fundo ideológico da reforma educacional petista" [Gramscian Marxism: Ideological Foundation for the PT's Education Reform] Ibérica Revista Interdisciplinar de Estudos Ibéricos e Ibero-Americano I, $\mathrm{n}^{\circ} 1$, Juiz de Fora.

Rubião, A. 2013. História da universidade: Genealogia de um 'modelo participativo' [University History: Genealogy of a 'Participatory Model']. São Paulo: Almedina. Kindle edition.

Sant'Ana, J. 2018. "Por que o Chile virou a referência de Bolsonaro. E o que pode ser feito aqui" [Why Chile Became Bolsonaro's Reference. And What Can Be Done Here] Gazeta do Povo, November 4. https:// www.gazetadopovo.com.br/politica/republica/por-que-o-chile-virou-a-referencia-economica-de-bo Isonaro-e-o-que-pode-ser-feito-aqui-0wdv3cbajjhj9×2x7m44dkosb/.

Saviani, D. 2008. "O legado educacional do regime militar." [The Educational Heritage of the Military Regime] Cadernos CEDES 28 (76): 291-312. doi:10.1590/S0101-32622008000300002.

Saviani, D. 2013. "A educação na Constituição Federal de 1988." [Education in the 1988 Federal Constitution] RBPAR 29: 207-221. doi:10.21573/vol29n22013.43520.

Semesp Institute. 2019. Mapa do ensino superior no Brasil, 2019 [Brazilian Higher Education Map, 2019]. https://www.semesp.org.br/pesquisas/mapa-do-ensino-superior-no-brasil-2019/.

Singer, A. 2012. Os sentidos do Lulismo: reforma gradual e pacto conservador [The Meanings of Lulism: Gradual Reform and Conservative Pact]. São Paulo: Companhia das Letras.

Sousa, A. H. 2019. Mercantilização e automação do ensino superior privado [Mercantilization and Automation of Private Higher Education]. http://fepesp.org.br/artigo/7078/.

Tavares, P. H. S. 2014. "Os fundos de investimento e o movimento do capital no ensino superior privado: mercantilização de novo tipo?" [Investment Funds and Capital Movement in Private Higher Education: A New Type of Commodification?] (Master's thesis). https://ppge.educacao. ufrj.br/teses2019/tPedro\%20Henrique\%20de\%20Sousa\%20Tavares.pdf.

Tragtemberg, M. 2004. Sobre educação, política e sindicalismo [On Education, Politics and Unionism]. São Paulo: UNESP. Kindle edition.

Turollo Jr. R. 2018. "Operações em universidades feriram liberdade de manifestação, afirma STF" [Police Operations at Universities Hurt Freedom of Demonstration, Says Supreme Court]. Folha de São Paulo, October 31. https://www1.folha.uol.com.br/cotidiano/2018/10/acoes-emuniversidades-feriram-liberdade-de-manifestacao-afirma-stf.shtml.

Unifesp. 2019. Manifestação do Conselho Universitário sobre o 'Future-se' [University Council Position on 'Future-se' Program]. https://www.unifesp.br/boletins-anteriores/item/3990-manifestacao-doconselho-universitario-da-unifesp-sobre-o-future-se.

Valente, R. 2020. "Ação sigilosa do governo mira professores e policiais antifascistas" [Secretive Government Action Targets Anti-Fascist Teachers and Police]. UOL, July 24. https://noticias.uol.com. br/colunas/rubens-valente/2020/07/24/ministerio-justica-governo-bolsonaro-antifascistas.htm.

Vinhais, H. 2013. "Estudo sobre o impacto da expansão das universidades Federais no Brasil" [Study on the Impact of the Expansion of Federal Universities in Brazil]. (Phd Dissertation). https://teses. usp.br/teses/disponiveis/12/12138/tde-20012014-152929/pt-br.php.

Weintraub, A. 2019. Minister of Education, on O Estado de São Paulo, April 30. https://educacao. estadao.com.br/noticias/geral,mec-cortara-verba-de-universidade-por-balburdia-e-ja-mira-unbuff-e-ufba,70002809579.

The World Bank. 2017. A Fair Adjustment: Efficiency and Equity of Public Spending in Brazil. https:// www.worldbank.org/en/country/brazil/publication/brazil-expenditure-review-report.

Zibas, D. M. L. 2008. "'A Revolta dos Pingüins' e o novo pacto educacional chileno." ["The Penguin Uprising" and the New Chilean Educational Pact] Revista Brasileira de Educação 13 (38): 199-220. doi:10.1590/S1413-24782008000200002. 